\title{
Transformational Leadership and Team Innovation: Integrating Team Climate Principles
}

\author{
Silke A. Eisenbeiss \\ University of Konstanz
}

\author{
Daan van Knippenberg \\ Erasmus University Rotterdam
}

\author{
Sabine Boerner \\ University of Konstanz
}

\begin{abstract}
Fostering team innovation is increasingly an important leadership function. However, the empirical evidence for the role of transformational leadership in engendering team innovation is scarce and mixed. To address this issue, the authors link transformational leadership theory to principles of M. A. West's (1990) team climate theory and propose an integrated model for the relationship between transformational leadership and team innovation. This model involves support for innovation as a mediating process and climate for excellence as a moderator. Results from a study of 33 research and development teams confirmed that transformational leadership works through support for innovation, which in turn interacts with climate for excellence such that support for innovation enhances team innovation only when climate for excellence is high.
\end{abstract}

Keywords: team innovation, transformational leadership, team climate

Innovation is a key factor in organizations' ability to create a sustainable competitive advantage (Kim, Min, \& Cha, 1999). For innovation organizations often rely on teamwork (Dumaine, 1994; Ilgen, Hollenbeck, Johnson, \& Jundt, 2005), and nearly the whole research and development (R\&D) sector emphasizes teamwork. Although this clearly points to the value of an understanding of the factors fostering team innovation, there is only a small amount of research dealing with team innovation (Kurtzberg \& Amabile, 2001; West, 2002b). The present study contributes to this emerging field by studying the role of transformational leadership in team innovation. Whereas the relationship with innovation is a major theme in conceptual analyses of transformational leadership (e.g., Bass, 1985; Bass \& Riggio, 2006; Tichy \& Devanna, 1986), empirical studies examining the relationship between transformational leadership and team innovation or team creativity as a subcomponent of innovation are scarce (Jung, 2001). Moreover, these studies have yielded contradictory results (Jaussi \& Dionne, 2003; Keller, 1992, 2006; Sosik, Kahai, \& Avolio, 1998; Waldman \& Atwater, 1994). Not surprisingly then, several authors have called for research on mediating and moderating effects (e.g., Avolio \& Yammarino, 2002; Hunt \& Conger, 1999; Yukl, 1999) to clarify how and when transformational leadership influences team innovation.

Silke A. Eisenbeiss and Sabine Boerner, Department of Politics and Management, University of Konstanz, Konstanz, Germany; Daan van Knippenberg, Rotterdam School of Management, Erasmus University Rotterdam.

Correspondence concerning this article should be addressed to Silke A. Eisenbeiss, Department of Politics and Management, University of Konstanz, P.O. Box D88, Konstanz, Germany 78457. E-mail: silke.eisenbeiss@uni-konstanz.de
In the current study, we address these calls. The point of departure for our analysis is the observation that research on transformational leadership and team innovation has not connected enough with insights from research in team dynamics. The present study aims to show that by more explicitly integrating insights from team research we can address core questions about the relationship between transformational leadership and team innovation. Research in team climate in particular has identified two main factors that are conducive to team innovation: support for innovation and climate for excellence (Anderson \& West, 1996, 1998; West, 1990). Support for innovation is defined as "practical support of attempts to introduce new and improved ways of doing things in the work environment" (West, 1990, p. 315) and thus refers to cooperation among team members and their mutual assistance in the development and application of novel ideas. Climate for excellence consists of shared group norms about "excellence of quality of task performance" (West, 1990, p. 313) and may be evidenced by each team member's commitment to high quality standards, critical appraisals, monitoring, and clear performance criteria within the team. Whereas support for innovation is proposed to influence the quantity of team innovation, climate for excellence is argued to be an important factor in the quality of team innovation (West, 1990). On the basis of an integration of the transformational leadership and the team climate frameworks, we proposed and empirically tested a model of the relationship between transformational leadership and team innovation that incorporates support for innovation as a mediator and climate for excellence as a moderator. First, we argue that the effect of transformational leadership on team innovation is mediated by support for innovation. Second, as providing uncritical support for innovation might lead to the generation and implementation of low-quality ideas within the team, we predict that support 
for innovation engenders team innovation only to the extent that teams have a climate for excellence.

\section{Theoretical Background and Hypotheses}

A consistent theme in the leadership literature has been to conceptualize transformational leadership as leadership targeted at change and innovation (Bass \& Riggio, 2006; Burns, 1978; Tichy \& Devanna, 1986). Innovation is understood here as "the intentional introduction and application within a role, group or organization of ideas, processes, products or procedures, new to the relevant unit of adoption, designed to significantly benefit the individual, the group, organization or wider society" (West \& Farr, 1990, p. 9). Creativity, or "the production of novel and useful ideas" (Amabile, 1988, p. 126), is an aspect of innovation, but innovation also includes the implementation of creative ideas. Team innovation thus can be operationalized as the combination of the quantity and quality of ideas that are developed and implemented (Pirola-Merlo \& Mann, 2004; West, 2002b).

Bass (1985) conceptualized transformational leadership as comprising four different components. Idealized influence refers to charismatic role modeling behavior of transformational leaders. Inspirational motivation means that transformational leaders provide meaning to followers' work by articulating an appealing or evocative vision for the team or the organization. Intellectual stimulation means that these leaders encourage followers to challenge existing assumptions, to reframe problems, and to approach old situations in new ways. Individualized consideration relates to coaching and mentoring behavior of transformational leaders. Whereas nontransformational (i.e., transactional) leadership is seen as focused on the status quo and fostering performance on well-defined tasks to meet set performance objectives, transformational leadership is proposed to highlight the necessity of change and to promote creativity (Avolio, 1994; Bass \& Riggio, 2006; Conger \& Kanungo, 1992). Therefore, transformational leadership should be especially suited to foster team innovation.

Transformational leaders do not settle for current states but articulate an appealing and challenging future vision. Transformational leaders also display unconventional and creative behavior and serve as role models for innovation (Howell \& Higgins, 1990). By providing intellectual stimulation, transformational leaders may also encourage followers to think "outside the box" (Jung, Chow, \& Wu, 2003) and to adopt an explorative thinking style. They point out different and unusual perspectives to look at old problems and to stimulate followers to critically appraise existing assumptions and working methods (Bass, 1985), which in turn should enhance team innovation. Moreover, by enhancing followers' self-efficacy (Pillai \& Williams, 2004) and intrinsic motivation (Shin \& Zhou, 2003), transformational leaders also enable followers to reach these future states.

Despite this wealth of conceptual work suggesting that transformational leadership and team innovation are related, there are only a few empirical studies of the relationship between transformational leadership and team innovation or team creativity. Moreover, these studies yielded contradictory results. Whereas Keller (1992, 2006) showed that transformational leadership is related to the performance of R\&D teams (which presumably reflects innovation), Waldman and Atwater (1994) did not find a relationship between transformational leadership and R\&D team performance, nor did Wilson-Evered, Härtel, and Neale (2001) observe a relationship between transformational leadership and team innovation. Experimental findings for team creativity are mixed as well. Both Jung (2001) and Sosik et al. (1998) found positive effects of transformational leadership on team creativity, but Jaussi and Dionne (2003) found a negative effect.

This mixed set of findings indicates that the impact of transformational leadership on team innovation may be dependent on contextual factors that have been ignored so far. Identifying contingencies, however, requires some clarity about the mediating team process. Hence, a clear hypothesis about the process mediating the relationship between transformational leadership and team innovation better positions us to identify a moderator of this relationship. Therefore, we first considered the team process mediating the relationship between transformational leadership and team innovation and used this as a point of departure for our analysis of the contingencies of this relationship. Unfortunately, mediating effects have rarely been investigated in transformational leadership research (van Knippenberg, van Knippenberg, De Cremer, \& Hogg, 2004; Yukl, 1999), and this observation holds especially at the team level (Dionne, Yammarino, Atwater, \& Spangler, 2004). Therefore, to identify this mediating process we relied on insights from team innovation research outside the leadership arena.

Team innovation research has studied team processes as antecedents of team innovation. Relating this stream of research to transformational leadership theory may help to explain how and when transformational leadership impacts team innovation. Although some of this work points to the role of factors such as readiness to change (e.g., Cummings \& Worley, 2000; Jones, Jimmieson, \& Griffiths, 2005) and openness to change (e.g., Miller, Johnson, \& Grau, 1994; Wanberg \& Banas, 2000), the issue for many organizations concerned with innovation does not seem to be organizational change so much as it seems to be innovation in products and services as part of the regular business processes. We therefore relied on work in the team climate that is more directly targeted at team innovation. Of particular relevance here is West's (1990) team climate theory, which was developed to integrate the existing research and to identify the crucial team factors that impact team innovation. This research suggests that support for innovation and climate for excellence are key factors in teams' ability to innovate. Whereas support for innovation seems to have a process focus (i.e., it reflects cooperative behavior in the process of realizing outcomes), climate for excellence seems to have an outcome focus (i.e., it reflects a shared concern with the quality of outcomes). Integrating transformational leadership theory and team climate theory, we proposed a theoretical model in which the effect of transformational leadership on team innovation is mediated by support for innovation and moderated by climate for excellence (see Figure 1). Thus, we extend West's theoretical and empirical work, in which he proposed and tested exclusively main effects of support for innovation and climate for excellence on team innovation (Burningham \& West, 1995; West \& Anderson, 1996; West et al., 2003).

\section{The Mediating Role of Support for Innovation}

Support for innovation is a team-level variable that reflects the extent to which the members of the team display supportive 


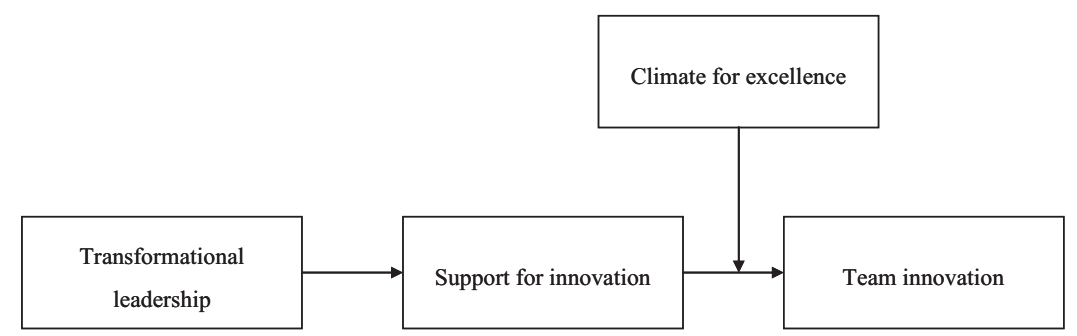

Figure 1. A model of the relationship between transformational leadership and team innovation.

behaviors aimed at facilitating the development and implementation of new ideas within the team. Although these supportive behaviors do not ensure higher quality innovations, support for innovation is proposed to be positively related to quantity of innovation (Burningham \& West, 1995).

Transformational leadership may enhance supportive behavior among team members by creating a shared commitment to innovation. Because transformational leadership triggers followers' exploratory and critical thinking processes, it may establish a working environment where unconventional and risk-taking approaches to solving problems are strongly valued and creativity is given high priority (Jung et al., 2003). Transformational leadership also emphasizes collective interests and induces team members to transcend their own self-interest for the betterment of the team (Bass, Avolio, Jung, \& Berson, 2003). As a result, team members attach high importance to team membership and are more willing to engage in efforts for the sake of the team (Bass \& Riggio, 2006). Thus, we expected transformational leadership to encourage team members to collaborate and to assist each other with idea development and implementation-that is, transformational leadership may engender support for innovation.

Hypothesis 1: Transformational leadership is positively related to support for innovation.

\section{The Moderating Role of Climate for Excellence}

Support for innovation may increase the number of ideas developed and implemented within the team because team members are more likely to share new ideas and, additionally, are willing to dedicate their time, share resources, and cooperate in implementing selected ideas. However, high levels of support for innovation also imply the risk that team members provide practical assistance uncritically to any suggested idea regardless of its quality and do not carefully select the most promising ones for innovation (West, 1990). Therefore, support for innovation may not always foster high-quality team innovation. As a case in point, whereas some researchers have found a positive relationship between support for innovation and team innovation (Bain, Mann, \& Pirola-Merlo, 2001; West \& Anderson, 1996; West et al., 2003), others have not (Wilson-Evered et al., 2001). This pattern of results suggests moderating effects on the relationship between support for innovation and team innovation.

On the basis of West's (1990) work in team climate, we proposed that climate for excellence moderates the relationship between support for innovation and team innovation. Climate for excellence is a team-level concept and refers to shared group norms for excellence. These norms do not specifically relate to innovation but reflect a more general concern with excellence of task performance (Anderson \& West, 1998; West, 1990). ${ }^{1}$ Climate for excellence would not necessarily be expected to feed into team innovation quantity, but it is proposed to render high-quality innovations more likely (Burningham \& West, 1995). We proposed that team climate for excellence is therefore an important moderator of the relationship between support for innovation and team innovation, because a high level of climate for excellence may ensure the quality of ideas generated and implemented.

First, under a high level of climate for excellence team members will critically reflect on the value of their own ideas before expressing them within the group, as they are deeply concerned with generating particularly novel and useful ideas. Second, given a high level of climate for excellence within the team, team members are more likely to improve and modify suggested ideas and then carefully select the most promising ones for implementation and reject the less useful ones. Third, as teams with a high level of climate for excellence are willing to work harder and to the maximum of their ability (West, 1990), they are more likely to overcome obstacles during the implementation process in order to transform selected ideas into sizable improvements in products, processes, or scientific knowledge. In contrast, if teams lack a shared concern with excellence, support for innovation is less likely to lead to the development of a large number of high-quality ideas that can be translated into tangible innovative outcomes.

Hypothesis 2: Climate for excellence moderates the relationship between support for innovation and team innovation such that support for innovation engenders team innovation only under high levels of climate for excellence.

In combination, the relationships predicted in Hypotheses 1 and 2 lead to the final step in our conceptual analysis: the prediction that support for innovation mediates the relationship between transformational leadership and innovation contingent on climate for excellence.

Hypothesis 3: Transformational leadership influences team innovation through its relationship with support for innovation and therefore engenders team innovation only under high levels of climate for excellence.

\footnotetext{
${ }^{1}$ Note that as such, climate for excellence reflects the extent to which the team has a concern for excellence and does not reflect climate strength (Schneider, Salvaggio, \& Subirats, 2002).
} 
Method

\section{Sample}

The sample comprised 33 R\&D teams from one research institute and four international R\&D companies engaged in the automotive, semiconductor, packaging, and scientific instruments industries. The majority of teams $(78.8 \%)$ worked in the development sector. $T$ tests indicated no substantial differences between R\&D teams. A total of 33 team leaders and 188 employees participated in the study. The team leaders were primarily men $(84.8 \%)$ and were between 32 and 52 years of age, with the average age being 42 . They had worked on average 11 years with the company and had a range of tenure from 2 to 25 years. Team leaders were embedded within the teams as direct supervisors and active participants of their respective teams. Team members had worked an average of 8 years with the company, ranging from 1 year to 33 years, and were between 25 and 57 years of age, with the average age being 37 years. The majority of team members (86.5\%) were men. Team size ranged from 5 to 22 members, with the average team size being 10.7 team members, and the average team tenure was 38.1 months. The minimum number of responding team members necessary for inclusion in the study was 2 members per team, with the average response rate within the teams being $57.0 \%$. Correlation analyses showed that the average response rate per team did not significantly relate to transformational leadership, support for innovation, climate for excellence, or team innovation.

\section{Procedure}

After having agreed to participate, each team leader was instructed about the objectives and procedure of the internet-based study via e-mail or telephone. Anonymous and strictly confidential data treatment was assured. When we launched the survey, team leaders were given the link to get on the Web site and a randomly generated team code. This code had to be entered on the first page of the survey to ensure that responses of leader and members belonging to the same team could be matched afterwards. Team leaders were asked to pass the provided information to their team members and to encourage them to participate. Team members were surveyed about perceptions of their team leader's transformational leadership, support for innovation, and climate for excellence. Information about team innovation was obtained from team leaders.

\section{Team Survey}

Transformational leadership. We measured transformational leadership using a 20-item scale from the Multifactor Leadership Questionnaire (MLQ) developed by Bass and Avolio (1995). The MLQ is the most common measure of transformational leadership (Judge, Woolf, Hurst, \& Livingston, 2006; Yukl, 1998) and operationalizes the four theoretically identified components of transformational leadership. Items were rated on a 7-point scale ranging from 1 (never) to 7 (almost always).

Support for innovation. We measured support for innovation using four items based on the Support for Innovation scale from the Team Climate Inventory (TCI) developed by Anderson and West (1998). These items assess concrete behavior supportive of innovation within the team (e.g., "Team members provide practical support for new ideas and their implementation"). All items were rated on a 7-point scale ranging from 1 (totally disagree) to 7 (totally agree).

Climate for excellence. We assessed climate for excellence using a seven-item scale from the TCI developed by Anderson and West (1998). All items were rated on a 7-point scale ranging from 1 (to a very little extent) to 7 (to a very high extent).

Control variable. Because team size has been found to impact innovation-related team processes and team innovation (Curral, Forrester, Dawson, \& West, 2001; Dailey, 1978), we decided to use it as a control variable and therefore asked team members for the size of their team.

\section{Supervisor Rating of Innovation}

To measure team innovation as defined by West (1990, 2002a), it is necessary to cover both stages of idea development and idea implementation and to take into account quantity as well as quality of innovation. Accordingly, team innovation was assessed using a 22-item scale based on Axtell et al. (2000) and on West and Anderson (1996). Team leaders had to indicate quantity and quality of ideas developed within the team as well as of ideas implemented. ${ }^{2}$ The scale included items such as "Please indicate to what extent your team develops ideas concerning new products or product improvements," "Please indicate to what extent the ideas concerning new products or product improvements were also implemented," and "When you think about your team's implemented ideas, how would you assess their novelty?" All items were rated on a 7-point scale ranging from 1 (e.g., no new ideas implemented) to 7 (e.g., many new ideas implemented).

\section{Results}

Results are described in the order in which the analyses were conducted. First, we report validity and reliability analyses of the scales, followed by a description of aggregation analyses. Second, in order to test our hypotheses, we followed a procedure recently developed by Preacher, Rucker, and Hayes (2007) to assess conditional indirect effects and moderated mediation effects, respectively.

\section{Validity and Reliability Analyses}

Transformational leadership, support for innovation, and climate for excellence. To determine the dimensional structure of our measure of transformational leadership, we conducted a con-

\footnotetext{
${ }^{2}$ One organization in our study sample agreed to provide us with some additional data on team innovation. The vice president of innovation of this organization rated the number of patents, the patents' value for the organization, and products' market success per team $(N=14)$ on a Likert scale ranging from 1 to 7 . In order to account for both the quantitative and qualitative aspects of team innovation, we created an additional index by adding up the number of patents and patents' value ratings. Because of the small sample size of rated teams we could not use those ratings as dependent variables in regression analyses but settled for calculating correlations with the team leaders' innovation ratings. All of those correlations were positive and had a medium effect size, ranging from .26 up to .31 (see Cohen \& Cohen, 1976).
} 
Table 1

Means, Standard Deviations, and Intercorrelations of Variables

\begin{tabular}{lrrrrrrr}
\hline \multicolumn{1}{c}{ Variable } & $M$ & $S D$ & 1 & 2 & 3 & 4 & 5 \\
\hline 1. Team size & 10.39 & 4.73 & - & & & & \\
2. Transformational leadership & 5.17 & 0.48 & -.11 & - & & \\
3. Support for innovation & 5.33 & 0.58 & -.28 & $.60^{*}$ & - & & \\
4. Climate for excellence & 4.91 & 0.47 & -.13 & $.39^{*}$ & $.52^{*}$ & - & \\
5. Team innovation & 4.76 & 0.84 & -.07 & .04 & .31 & .14 & - \\
$* p<.05$, two-tailed. & & & & & &
\end{tabular}

firmatory factor analysis using AMOS 5.0 to test a two-level factor model. Following Bass's (1985) conception of transformational leadership, this model contained the four components of transformational leadership as four different factors at the first level and transformational leadership as an underlying single factor at the second level. Because modification indexes indicated that the 11th item could best be left out of analysis, we conducted the confirmatory factor analysis without this item and found support for the expected two-level factor structure, $\chi^{2}(148, N=188) / d f=2.55$, confirmatory fit index $(\mathrm{CFI})=.90$, root-mean-square error of approximation (RMSEA) $=.09$.

Subsequently, in order to ensure discriminative validity of transformational leadership, support for innovation, and climate for excellence, we performed confirmatory factor analyses for different models. We compared a three-factor model that contained transformational leadership as two-level factor construct as well as support for innovation and climate for excellence as separate factors to a two-factor model in which support for innovation and climate for excellence were conceptualized as one factor. As a further alternative, we also tested a simple one-factor model. As expected, we found that the three-factor model, $\chi^{2}(722, N=$ $188) / d f=1.90, \mathrm{CFI}=.90, \mathrm{RMSEA}=.07$, showed a satisfying fit, whereas both the two-factor model, $\chi^{2}(724, N=188) / d f=2.16$, $\mathrm{CFI}=.87$, RMSEA $=.08$, and the one-factor model, $\chi^{2}(812, N=$ $188) / d f=4.03$, CFI $=.65$, RMSEA $=.13$, did not fit well. Additionally, the chi-square test for model comparison indicated that the three-factor model fit the data significantly better than the two-factor model, $\Delta \chi^{2}(2, N=188)=103, p<.001$. The analyses of internal homogeneity showed acceptable results as well. Cronbach's alpha for transformational leadership was .95 and .84 for support for innovation. As item analysis for climate for excellence pointed to an improvement of Cronbach's alpha if the sixth item was deleted, we decided to do so. ${ }^{3}$ Cronbach's alpha was .77 .

Team innovation. Because the scale used for measuring team innovation comprised 22 items, the sample size of the team leaders $(N=33)$ was too small to conduct any factor analysis to test for the scale's expected single-factor structure. However, Cronbach's alpha for team innovation was .93 , indicating excellent internal homogeneity.

\section{Aggregation Analyses}

Analysis of within-group variance. To justify the aggregation of individual team members' survey responses to the team level, we calculated interrater agreement following the formula developed by James, Demaree, and Wolf (1984) for the transformational leadership, support for innovation, and climate for excellence scales. The $r_{\mathrm{wg}}$ for transformational leadership was $.96, r_{\mathrm{wg}}$ for support for innovation was .95 , and $r_{\mathrm{wg}}$ for climate for excellence was .89. All the $r_{\mathrm{wg}}$ values were above the critical cutoff value of .70 (James et al., 1984) and thus suggested that it was appropriate to aggregate individual responses to the team level. However, as the $r_{\text {wg }}$ has been criticized for using a uniform distribution, we also calculated the $a_{\mathrm{wg}}$ index. Brown and Hauenstein (2005) developed the $a_{\mathrm{wg}}$ as alternative interrater agreement index in order to overcome the problems with the $r_{\mathrm{wg}}$ index. The $a_{\mathrm{wg}}$ for transformational leadership was .65, $a_{\mathrm{wg}}$ for support for innovation was .71, and $a_{\mathrm{wg}}$ for climate for excellence was .65. According to Brown and Hauenstein, $a_{\mathrm{wg}}$ values above .60 indicate acceptable interrater agreement.

Analysis of between-groups variance. To determine the between-groups variance and, therefore, to assess the discriminating power of the scales, we performed one-way analyses of variance (ANOVAs) for the transformational leadership, support for innovation, and climate for excellence scales. For each scale the $F$ value was statistically significant, implying substantial differences between groups.

\section{Hypothesis Testing}

Table 1 presents means and standard deviations for all variables in the study as well as the correlation matrix of all these variables at the team level. To test our hypotheses and thus our overall theoretical model (see Figure 1), we followed a procedure to analyze conditional indirect effects developed by Preacher et al. (2007). A conditional indirect effect covers mediated moderation and moderated mediation, respectively, and is defined as "the magnitude of an indirect effect at a particular value of a moderator (or at particular values of more than one moderator)" (Preacher et al., 2007, p. 186). Several authors (Edwards \& Lambert, 2007; Muller, Judd, \& Yzerbyt, 2005) have recently asked for precise approaches to assess the presence, strength, and significance of such conditional indirect effects. Preacher et al. (2007) tried to address those demands by putting forward a procedure that offers the possibility to accurately test theoretical expectations about which path of the hypothesized mediation model will be moderated.

The procedure involves the following four steps (Preacher et al., 2007). The first two steps represent conventional regression anal-

\footnotetext{
${ }^{3}$ Please note that the subsequently reported analyses for hypothesis testing led to identical results when we used the original scales (e.g., including the 11th item of the MLQ scale and the 6th item of the climate for excellence scale).
} 
yses. In the first step, the mediator variable is regressed on the independent variable, which should be a significant predictor of the mediator variable. In the second step, a multiple regression is conducted that predicts the dependent variable from the mediator, the moderator, the independent variable, and the interaction between the moderator and the mediator. The interaction effect should be statistically significant as well. Following the recommendations of Aiken and West (1996), any variable used as a component of the interaction term is mean-centered. The third and the fourth steps test the conditional indirect effect of the independent variable on the dependent variable by probing specific indirect effects of the independent variable on the dependent variable at certain values of the moderator variable. Whereas the test conducted in the third step assumes normality of sampling distribution, the test conducted in the fourth step is nonparametric and relies on a bootstrapping procedure.

The first step shows that transformational leadership significantly predicted support for innovation, thus confirming Hypothesis 1 (see Table 2). The second step yielded a significant interaction between support for innovation and climate for excellence, implying that the relationship between support for innovation and team innovation is moderated by climate for excellence. We plotted this interaction following Aiken and West (1996). As shown in Figures 2 and 3, both transformational leadership and support for innovation positively related to team innovation only under high climate for excellence. Hypothesis 2 was thus confirmed as well. Both the subsequent tests of the conditional indirect effect (Steps 3 and 4) showed that the indirect effect of transformational leadership on team innovation was significant only when climate for excellence was high, thus providing support for Hypothesis 3 (see Table 2 for all statistics). The indirect effect of transformational leadership on team innovation was not significant for low climate for excellence.

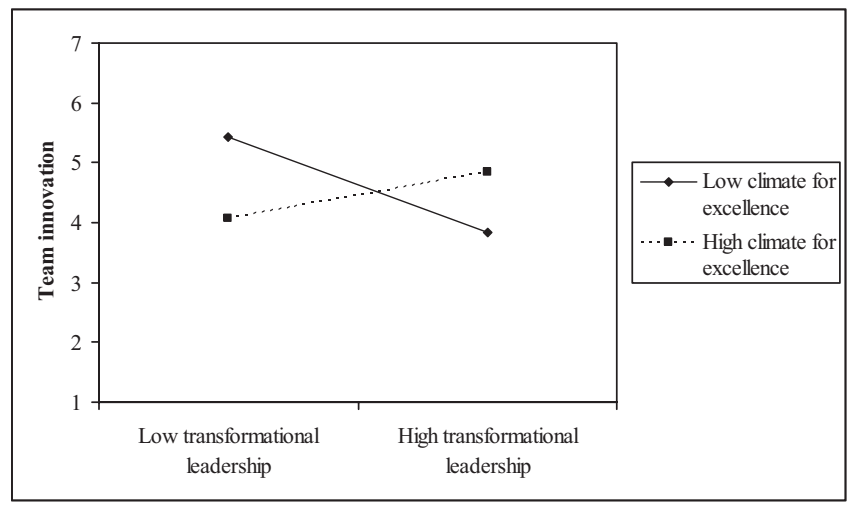

Figure 2. Interaction effect between transformational leadership and climate for excellence on team innovation.

\section{Discussion}

Addressing uncertainties about mediating and moderating variables in the relationship between transformational leadership and team innovation as well as addressing calls for research identifying mediating variables and moderators in transformational leadership more generally, we found that transformational leadership was positively related to support for innovation (Hypothesis 1), which in turn fostered team innovation only under high levels of climate for excellence (Hypothesis 2). Moreover, we established a conditional indirect effect of transformational leadership on team innovation, which was mediated by support for innovation and moderated by climate for excellence (Hypothesis 3). As our results showed, transformational leadership may be instrumental in team innovation but is not sufficient to stimulate team innovation. For teams to innovate it is also important that team members share a concern for high-quality performance (i.e., climate for excellence).

Table 2

Test of Overall Model

\begin{tabular}{|c|c|c|c|c|}
\hline Variable & $b$ & $S E b$ & $t$ & $R^{2}$ \\
\hline \multicolumn{4}{|l|}{ Mediator variable model (Step 1): Support for innovation } & .40 \\
\hline Team size & & 0.02 & -1.50 & \\
\hline Transformational leadership & & 0.03 & $4.04^{*}$ & \\
\hline \multicolumn{4}{|l|}{ Dependent variable model (Step 2): Team innovation } & .30 \\
\hline Team size & & 0.11 & 0.26 & \\
\hline Transformational leadership & -0.40 & 0.24 & -1.67 & \\
\hline Support for innovation & 1.33 & 1.38 & 0.96 & \\
\hline Climate for excellence & -0.70 & 1.38 & -0.51 & \\
\hline Support for Innovation $\times$ Climate for Excellence & 6.73 & 2.64 & $2.55^{*}$ & \\
\hline \multicolumn{2}{|l|}{ Level of climate for excellence } & $\begin{array}{l}\text { Indirect } \\
\text { effect }\end{array}$ & $S E$ & $Z$ \\
\hline \multicolumn{5}{|c|}{ Conditional indirect effects assuming normal distribution (Step 3) } \\
\hline$-1 S D$ & & -.22 & .26 & -0.82 \\
\hline Mean & & .15 & .17 & 0.87 \\
\hline$+1 S D$ & & .51 & .21 & $2.36^{*}$ \\
\hline \multicolumn{5}{|l|}{ Conditional indirect effects with bootstrap method (Step 4) } \\
\hline$-1 S D$ & & -.22 & .26 & -0.82 \\
\hline Mean & & .15 & .17 & 0.87 \\
\hline$+1 S D$ & & .51 & .21 & $2.36^{*}$ \\
\hline
\end{tabular}




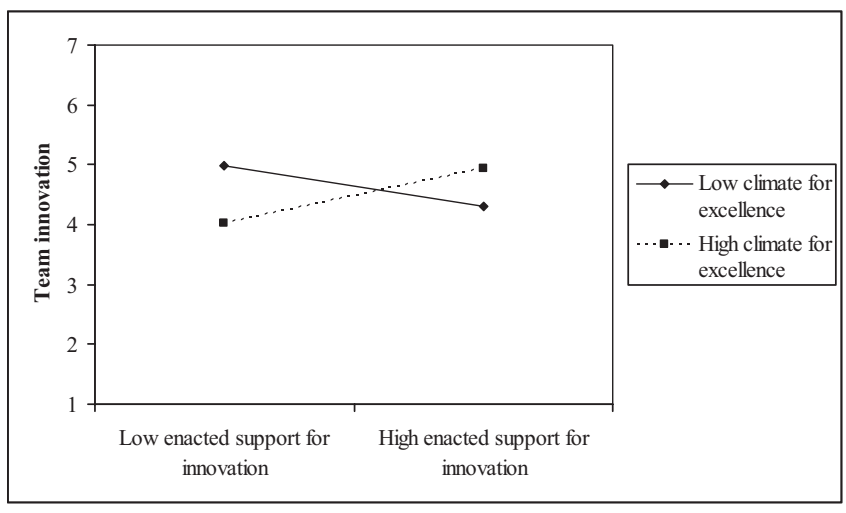

Figure 3. Interaction effect between support for innovation and climate for excellence on team innovation.

\section{Theoretical Implications}

The current study contributes to the team innovation literature by integrating theories of transformational leadership and team climate. As our results show, combining different streams of research advances our understanding of the relationship between leadership, team processes, and team outcomes. To date, there have been few efforts to develop such integrative models, and the present findings suggest that we may advance our understanding of leadership and team performance by further exploring such integrations in future research. For instance, Atwater and Bass (1994) attempted to link transformational leadership to team factors like cohesion and conflict management, whereas innovation research has examined the role that cohesion (Nyström, 1979) and conflict (De Dreu, 2006) play for team innovation. Additionally, as the present study shows, such conceptual integrations may also be conducive to the identification of important moderating variables.

Our research also adds to team climate theory by extending and empirically testing principles of West's (1990) model. West provided a comprehensive classification schema for team factorsfirst and foremost, support for innovation and climate for excellence-that are proposed to directly influence team innovation. Extending this model, we proposed and empirically confirmed an interaction effect such that support for innovation may foster team innovation only if combined with high levels of climate for excellence. Thus, support for innovation seems to be a necessary but not a sufficient precursor of team innovation.

\section{Limitations}

Apart from these contributions, our study is not without limitations. First, we did not get the permission from the organizations to collect the longitudinal data that would have been preferable in view of the causal chain implied in our conceptual analysis. Given the study's cross-sectional design, we cannot draw conclusions about causal relationships. Second, our study could be criticized for the small sample size of 33 teams. However, finding relationships, especially moderating effects, in a relative small sample indicates large effect sizes (Cohen, 1992). Third, we were not able to assess objective measures of team innovation (e.g., number of patents). Accordingly, future research would clearly benefit from longitudinal and experimental designs incorporating objective measures of team innovation.

\section{Managerial Implications}

Given the importance of climate for excellence as a contextual factor, these questions arise: Where does climate for excellence come from, and how can it be fostered within organizations? As climate for excellence consists of shared norms about high-quality standards, it may help to look at the social psychology literature. Sherif's (1936) seminal work showed that norms quickly develop in the first stages of team development on the basis of reciprocal and mainly unconscious influence processes among team members. Once established, shared norms are relatively resistant to revision (MacNeil \& Sherif, 1976). Consequently, organizations should try to boost climate for excellence right from the beginning by anchoring such norms in their organizational vision and mission and by promoting their importance in everyday business.

We conclude that organizations are able to facilitate team creativity and innovation by stimulating both support for innovation and climate for excellence. As transformational leadership was shown to predict support for innovation, organizations can influence supportive behavior for innovation by promoting a transformational leadership style among team leaders through selection and leadership development programs. Previous research has shown that transformational leadership can be trained in focused training programs (Avolio, 1999; Barling, Weber, \& Kelloway, 1996). The present findings also clearly indicate that such efforts should be complemented by attempts to build a climate for excellence. Through such combined efforts, organizations may profit from team's ability to produce high-quality innovations.

\section{References}

Aiken, L. S., \& West, S. G. (1996). Multiple regression: Testing and interpreting interactions. Newbury Park, CA: Sage.

Amabile, T. M. (1988). A model of creativity and innovation in organizations. Research in Organizational Behavior, 10, 123-167.

Anderson, N. R., \& West, M. A. (1996). The Team Climate Inventory: Development of the TCI and its applications in teambuilding for innovativeness. European Journal of Work and Organizational Psychology, 5(1), 53-66.

Anderson, N. R., \& West, M. A. (1998). Measuring climate for work group innovation: Development and validation of the Team Climate Inventory. Journal of Organizational Behavior, 19, 235-258.

Atwater, D. C., \& Bass, B. M. (1994). Transformational leadership in teams. In B. M. Bass \& B. J. Avolio (Eds.), Improving organizational effectiveness through transformational leadership (pp. 48-83). Thousand Oaks, CA: Sage.

Avolio, B. J. (1994). Total quality and leadership. In B. M. Bass \& B. J. Avolio (Eds.), Improving organizational effectiveness through transformational leadership (pp. 121-145). Thousand Oaks, CA: Sage.

Avolio, B. J. (1999). Full leadership development. Thousand Oaks, CA: Sage.

Avolio, B. J., \& Yammarino, F. J. (2002). Introduction, and overview of, transformational and charismatic leadership. In B. J. Avolio \& F. J. Yammarino (Eds.), Transformational and charismatic leadership: The road ahead (pp. xvii-xxiii). Amsterdam: JAI Press.

Axtell, C. M., Holman, D. J., Unsworth, K. L., Wall, T. D., Waterson, P. E., \& Harrington, E. (2000). Shopfloor innovation: Facilitating the suggestion and implementation of ideas. Journal of Occupational and Organizational Psychology, 73, 265-285. 
Bain, P. G., Mann, L., \& Pirola-Merlo, A. (2001). The innovation imperative: The relationship between team climate, innovation, and performance in research and development teams. Small Group Research, 32(1), 55-73.

Barling, J., Weber, T., \& Kelloway, E. K. (1996). Effects of transformational leadership training on attitudinal and financial outcomes: A field experiment. Journal of Applied Psychology, 81(6), 827-832.

Bass, B. M. (1985). Leadership and performance beyond expectations. New York: Free Press.

Bass, B. M., \& Avolio, B. J. (1995). MLQ Multifactor Leadership Questionnaire [Technical report]. Redwood City, CA: Mind Garden.

Bass, B. M., Avolio, B. J., Jung, D. I., \& Berson, Y. (2003). Predicting unit performance by assessing transformational and transactional leadership. Journal of Applied Psychology, 88(2), 207-218.

Bass, B. M., \& Riggio, R. E. (2006). Transformational leadership. Mahwah, NJ: Erlbaum.

Brown, R. D., \& Hauenstein, N. M. A. (2005). Interrater agreement reconsidered: An alternative to the $r_{\mathrm{wg}}$ indices. Organizational Research Methods, 8(2), 165-184.

Burningham, C., \& West, M. A. (1995). Individual, climate, and group interaction processes as predictors of work team innovation. Small Group Research, 26(1), 106-117.

Burns, J. M. (1978). Leadership. New York: Harper \& Row.

Cohen, J. (1992). A power primer. Psychological Bulletin, 112(1), 155159 .

Cohen, J., \& Cohen, P. (1976). General multiple regression and correlation analysis. In P. M. Bentler, D. J. Lettieri, \& G. A. Austin (Eds.), Data analysis strategies and designs for substance abuse research (pp. 159178). Rockville, MD: National Institute on Drug Abuse.

Conger, J. A., \& Kanungo, R. N. (1992). Perceived behavioural attributes of charismatic leadership. Canadian Journal of Behavioural Science, 24(1), 86-102.

Cummings, T. G., \& Worley, C. (2000). Organizational development and change. Cincinnati, OH: South-Western.

Curral, L. A., Forrester, R. H., Dawson, J. F., \& West, M. A. (2001). It's what you do and the way that you do it: Team task, team size, and innovation-related group processes. European Journal of Work and Organizational Psychology, 10(2), 187-204.

Dailey, R. C. (1978). The role of team and task characteristics in R\&D team collaborative problem solving and productivity. Management Science, 24(15), 1579-1588.

De Dreu, C. K. W. (2006). When too little or too much hurts: Evidence for a curvilinear relationship between task conflict and innovation in teams. Journal of Management, 32(1), 83-107.

Dionne, S. D., Yammarino, F. J., Atwater, L. E., \& Spangler, W. D. (2004). Transformational leadership and team performance. Journal of Organizational Change Management, 17(2), 177-193.

Dumaine, B. (1994, September 5). The trouble with teams. Fortune, 130(5), 86-92.

Edwards, J. R., \& Lambert, L. S. (2007). Methods for integrating moderation and mediation: A general analytic framework using moderated path analysis. Psychological Methods, 12(1), 1-22.

Howell, J. M., \& Higgins, C. A. (1990). Champions of technological innovation. Administrative Science Quarterly, 35, 317-341.

Hunt, J. G., \& Conger, J. A. (1999). From where we sit: An assessment of transformational and charismatic leadership research. The Leadership Quarterly, 10(3), 335-345.

Ilgen, D. R., Hollenbeck, J. R., Johnson, M., \& Jundt, D. (2005). Teams in organizations: From input-process-output models to IMOI models. Annual Review of Psychology, 56, 517-543.

James, L. R., Demaree, R. G., \& Wolf, G. (1984). Estimating within-group interrater reliability with and without response bias. Journal of Applied Psychology, 69(1), 85-98.

Jaussi, K. S., \& Dionne, S. D. (2003). Leading for creativity: The role of unconventional leader behavior. The Leadership Quarterly, 14, 475498.

Jones, R. A., Jimmieson, N. L., \& Griffiths, A. (2005). The impact of organizational culture and reshaping capabilities on change implementation success: The mediating role of readiness for change. Journal of Management, 42(2), 361-386.

Judge, T. A., Woolf, E. F., Hurst, C., \& Livingston, B. (2006). Charismatic and transformational leadership: A review and agenda for future research. Zeitschrift für Arbeits- und Organisationspsychologie, 50(4), 203-214.

Jung, D. I. (2001). Transformational and transactional leadership and their effects on creativity in groups. Creativity Research Journal, 13(2), 185-195.

Jung, D. I., Chow, C., \& Wu, A. (2003). The role of transformational leadership in enhancing organizational innovation: Hypotheses and some preliminary findings. The Leadership Quarterly, 14, 525-544.

Keller, R. T. (1992). Transformational leadership and the performance of research and development project groups. Journal of Management, 18(3), 489-501.

Keller, R. T. (2006). Transformational leadership, initiating structure, and substitutes for leadership: A longitudinal study of research and development project team performance. Journal of Applied Psychology, 91(1), 202-210.

Kim, Y., Min, B., \& Cha, J. (1999). The roles of R\&D team leaders in Korea: A contingent approach. R\&D Management, 18(2), 153-165.

Kurtzberg, T. R., \& Amabile, T. M. (2001). From Guilford to creative synergy: Opening the black box of team-level creativity. Creativity Research Journal, 13(3-4), 285-294.

MacNeil, M. K., \& Sherif, M. (1976). Norm change over subject generations as a function of arbitrariness of prescribed norms. Journal of Personality and Social Psychology, 34(5), 762-773.

Miller, V. D., Johnson, J. R., \& Grau, J. (1994). Antecedents to willingness to participate in a planned organizational change. Journal of Applied Communication Research, 22, 59-80.

Muller, D., Judd, C. M., \& Yzerbyt, V. Y. (2005). When moderation is mediated and mediation is moderated. Journal of Personality and Social Psychology, 89(6), 852-863.

Nyström, H. (1979). Creativity and innovation. Chichester, United Kingdom: Wiley.

Pillai, R., \& Williams, E. A. (2004). Transformational leadership, selfefficacy, group cohesiveness, commitment, and performance. Journal of Organizational Change Management, 17(2), 144-159.

Pirola-Merlo, A., \& Mann, L. (2004). The relationship between individual creativity and team creativity: Aggregating across people and time. Journal of Organizational Behavior, 25, 235-257.

Preacher, K. J., Rucker, D. D., \& Hayes, A. F. (2007). Addressing moderated mediation hypotheses: Theory, methods, and prescriptions. Multivariate Behavioral Research, 42(1), 185-227.

Schneider, B., Salvaggio, A. N., \& Subirats, M. (2002). Climate strength: A new direction for climate research. Journal of Applied Psychology, $87(2), 220-229$.

Sherif, M. (1936). The psychology of social norms. New York: Harper \& Row.

Shin, S. J., \& Zhou, J. (2003). Transformational leadership, conservation, and creativity: Evidence from Korea. Academy of Management Journal, 46(6), 703-714.

Sosik, J. J., Kahai, S. S., \& Avolio, B. J. (1998). Transformational leadership and dimensions of creativity: Motivating idea generation in computer-mediated groups. Creativity Research Journal, 11(2), 111121.

Tichy, N. M., \& Devanna, M. A. (1986). The transformational leader. Training and Development Journal, 40(7), 27-32.

van Knippenberg, D., van Knippenberg, B., De Cremer, D., \& Hogg, M. A. 
(2004). Leadership, self, and identity: A review and research agenda. The Leadership Quarterly, 15, 825-856.

Waldman, D. A., \& Atwater, L. E. (1994). The nature of effective leadership and championing processes at different levels in a R\&D hierarchy. The Journal of High Technology Management Research, 5(2), 233-245.

Wanberg, C. R., \& Banas, J. T. (2000). Predictors and outcomes of openness to changes in a reorganizing workplace. Journal of Applied Psychology, 85(1), 132-142.

West, M. A. (1990). The social psychology of innovation in groups. In M. A. West \& J. L. Farr (Eds.), Innovation and creativity at work: Psychological and organizational strategies (pp. 309-333). Chichester, United Kingdom: Wiley.

West, M. A. (2002a). Ideas are ten a penny: It's team implementation not idea generation that counts. Applied Psychology: An International Review, 51(3), 411-424.

West, M. A. (2002b). Sparkling fountains or stagnant ponds: An integrative model of creativity and innovation implementation in work groups. Applied Psychology: An International Review, 51(3), 355-424.

West, M. A., \& Anderson, N. R. (1996). Innovation in top management teams. Journal of Applied Psychology, 81(6), 680-693.
West, M. A., Borrill, C. S., Dawson, J. F., Brodbeck, F. C., Shapiro, D. A., \& Haward, B. (2003). Leadership clarity and team innovation in health care. The Leadership Quarterly, 14, 393-410.

West, M. A., \& Farr, J. L. (1990). Innovation at work. In M. A. West \& J. L. Farr (Eds.), Innovation and creativity at work: Psychological and organizational strategies (pp. 3-13). Chichester, United Kingdom: Wiley.

Wilson-Evered, E., Härtel, C. E. J., \& Neale, M. (2001). A longitudinal study of work group innovation: The importance of transformational leadership and morale. Advances in Health Care Management, 2, 315340 .

Yukl, G. (1998). Leadership in organizations. Upper Saddle River, NJ: Prentice-Hall.

Yukl, G. (1999). An evaluation of conceptual weaknesses in transformational and charismatic leadership theories. The Leadership Quarterly, $10(2), 285-305$. 